\title{
Author Correction: WWOX controls hepatic HIF1a to suppress hepatocyte proliferation and neoplasia
}

Muhannad Abu-Remaileh', Abed Khalaileh², Eli Pikarsky ${ }^{1}$ and Rami I. Aqeilan ${ }^{1,3}$

Correction to: Cell Death and Disease (2018); https://doi. org/10.1038/s41419-018-0510-4; published online 03 May 2018.

Since the publication of this Article, the authors reported that duplication had mistakenly occurred in Fig. 3a and $d-$ panels that display H\&E.
The corrected Article appears online together with this erratum.

Published online: 23 November 2018

\footnotetext{
Correspondence: Rami I. Aqeilan (ramiaq@mail.huji.ac.il)

${ }^{1}$ The Lautenberg Center for General and Tumor Immunology, Department of Immunology and Cancer Research-IMRIC, Hebrew University-Hadassah Medical School, Jerusalem, Israel

${ }^{2}$ Department of Surgery, Hebrew University-Hadassah Medical, Jerusalem, Israel

${ }^{3}$ Department of Cancer Biology and Genetics, Wexner Medical Center, The Ohio State University, Columbus, OH, USA

Edited by G. Melino
}

\section{(c) The Author(s) 2018}

(c) Open Access This article is licensed under a Creative Commons Attribution 4.0 International License, which permits use, sharing, adaptation, distribution and reproduction in any medium or format, as long as you give appropriate credit to the original author(s) and the source, provide a link to the Creative Commons license, and indicate if changes were made. The images or other third party material in this article are included in the article's Creative Commons license, unless indicated otherwise in a credit line to the material. If material is not included in the article's Creative Commons license and your intended use is not permitted by statutory regulation or exceeds the permitted use, you will need to obtain permission directly from the copyright holder. To view a copy of this license, visit http://creativecommons.org/licenses/by/4.0/. 